\title{
Developing Creative Thinking Skills in Learning at Higher-Educational Institution of Teacher
}

\author{
Luthfiyah Nurlela \\ Culinary Arts of Home Economics Department \\ Surabaya State University, Surabaya, INDONESIA \\ luthfiyahn@yahoo.com
}

\begin{abstract}
The ability to think creatively is necessary for human resource competencies in order to boost global competitiveness. The aims of this study were: (1) developing a textbook on learning strategies to think creatively; (2) developing course materials applying creative thinking skills in the Bachelor Program of Culinary Arts. The study employed a developmental research using the 4-D (Define, Design, Develop, and Disseminate) model of development (Thiagarajan, 1974). This preliminary research was up to the Develop stage. The subjects were the students of the program. The data were collected using observation and questionnaires, and analyzed using descriptive-quantitatively. The results showed that the textbook was excellent as the total score attained was 3.41 , a very feasible category. The feasibility was supported by the textbook comprehensibility as assessed by the students and in accordance with the undergraduate level. The results regarding the course materials reached a score of 3.42, i.e. good category.
\end{abstract}

Index Terms - creative thinking skills; learning strategies; culinary arts.

\section{Introduction}

One of the international studies on students' cognitive abilities were TIMSS (Trends in Mathematics and Science Study) conducted by the IEA (International Association for the Evaluation of Educational Achievement). It revealed that in 2007 and 2011, more than 95\% of Indonesian learners were only able to achieve intermediate level in math, whereas for example in Taiwan nearly $50 \%$ of the learners were able to reach high and advanced levels. In the field of science, the achievement was similar in which more than $95 \%$ of the Indonesian were only able to reach the intermediate level, while nearly $40 \%$ of the Taiwanese learners were able to achieve high level and advanced levels.

The understanding, application, and reasoning aspects within the realm of cognitive abilities such as one applied to the TIMSS can be used to show the students' thinking skills profile. Of these three aspects, the aspects of understanding and application belong to the basic thinking skills or lower order thinking. While the reasoning aspects included in the higher order thinking skills. As the results of the TIMSS indicated, the Indonesian students' ability to think critically was still low. This occurred because in the learning process in Indonesian schooling contexts, the students in general are less stimulated to increase their high-level thinking skills. This kind of thinking skills is defined as the more expanding cultivation of the mind to find new challenges or to develop new ideas and to find new ways of looking at problems and opportunities. It is an important source to gain a global competitive advantage.
However, learners generally do not possess the basic thinking skills. Few teachers and lecturers develop the skills. This fact is consistent with the results of some previous research indicating that the majority of the students ranging from the middle school to the post-graduate levels have a low ability to think critically [1]. The decrease in the elaboration scores implied that the subjects were constantly losing "their ability to elaborate upon ideas and detailed and reflective thinking as they were less motivated to be creative by home, school, and society overall [2]. Therefore, the transformation of education is essential for any kind of learning from rote learning to learning constructively, or from surface learning to in-depth or complex one [3]. Learners must be convinced that the lesson they have interesting and meaningful, because it can help them to understand about the world and themselves. The learning process should be able to increase the power of imagination, creativity and ability to think logically.

A great number of previous related studies have revealed that the quality of teachers is a prerequisite towards the realization of quality education. A number of studies, for instance, have been conducted by Center for Science and Mathematics at School (PSMS) of Unesa have provided strong evidence that the quality of teaching materials is also a prerequisite for the realization of quality education [4][5][6][7][8][9]. Qualified teachers therefore need quality learning tools to realize quality learning.

Moreover, study skills and innovation have become increasingly recognized as skills that distinguish students who are prepared for life and work environments becoming increasingly complex in the 21st century, and students who are not ready for those challenges. Other things essential for facing future challenges include focus on creativity, critical thinking, problem solving, learning strategies, communication and collaboration.

This research therefore focused on improving the quality of student teachers, particularly of the Culinary Arts Department of Surabaya State University (Unesa). Specifically, it was aimed at: (1) developing a textbook on learning strategies to think creatively; (2) developing course materials applying creative thinking skills in the Bachelor Program of Culinary Arts.

\section{Teaching Creative Thinking Skills}

\section{A. What is Creative Thinking?}

Creativity, in its simplest literal definition is a process to produce something new that requires intelligence and imagination (Oxford Dictionary of English, 2010). It is the 
ability to create, by the originality of thought, showing imagination [10]. It emphasizes more on process than the end result. A process that is different from one existing before can be categorized as the result of one's creativity.

In the psychological context, creativity is the ability to produce a composition, product, or idea of what is essentially new, previously unknown, and original [11]. It can be imaginative activity or synthesis of thought originated not only by summarizing. Creativity may cover the establishment of patterns, the combined information derived from previous experience and transplantation of old ties to the new situation including the creation of a new correlation. Creativity must have a specified purpose or purposes, not mere fantasy, although as a result, it is perfect and complete. Creativity may take the form of artistic, literary, scientific or product which may be procedural or methodological. Creativity is a mental process that is unique- something that is solely to produce something new, different from the original that includes a specific thought that constitute different ideas and thoughts freely (convergent thinking). It follows the path of convergence where the idea uses the information available to reach the conclusion and leads to the correct answer.

Creativity is the ability to create something new, the ability to provide new ideas that can be applied in problem solving, or the ability to see the new relationship between or among pre-existing elements [12]. One's creativity can be seen from his or her behavior or activities. According [13], what is more important in the emergence of creativity is not something that has never been known before, but the products of creativity which is new for themselves and do not have to be something new for others or the world in general. Based on the above definition, the researcher has concluded that creativity is the potential of individual's creative power as a form of thinking in finding the relationship between or among existing elements or new ways to deal with problems that appear in the form of selfmotivation and a strong desire to be creative.

To sum up, creative thinking is included in the higherorder thinking. It means "inventing something new, thinking up something from scratch, and putting things together in a new way". This kind of thinking help learners solve problems and make decisions [14].

\section{B. How to Teach Creative Thinking Skills}

With regard to how to teach creative thinking, the questions asked by teachers must be divergent questions if learning refers to the creative process, learning should start from finding a problem, to solve it, and to communicate it [12]. Open questions (divergent) will provide an opportunity for students to give more than one correct answers and to encourage students to think differently and flexibly. With relevance to [15], teachers can make students have courage to behave creatively through: (1) a task which not only has a certain correct answer (many/all answers are correct); (2) tolerating eccentric answers; (3) emphasizing on process not only results; (4) encouraging the students to try, to determine by themselves when having less clear/complete information, to have their own interpretation of events associated with the knowledge or what is being observed; and (5) providing a balance between what is structured and spontaneous/expressive.
There are several strategies for teaching creative thinking skills. They include (1) inductive learning, (2) inquiry learning, (3) discovery learning, (4) problem solving, (5) scientific approach to learning, and (6) metaphorming.

\section{1) Inductive learning}

Inductive learning which includes inquiry, problem solving, discovery, and the scientific method, is considered as an appropriate strategy to teach creative thinking skills [16]. Likewise with metaphorming strategy, which has a connection component, discovery, creation, application, is also believed to be able to develop the thinking skills of learners [17].

\section{2) Inquiry learning}

Inquiry learning is a learning activity that involves students optimally by using the students' ability to seek out and investigate things (objects, people or events) in a systematic, critical, logical, analytical way so that they can formulate their own findings with confidence. Inquiry learning emphasizes the process of searching and finding. The subject matter is not given directly. The role of the students in this study is to seek and find their own subject matter, while the teacher acts as a facilitator and mentor.

\section{3) Discovery learning}

Problem solving is a method of teaching in which students are faced with a problem that must be solved based on data or information that is accurate so that they can draw a conclusion. While problem solving is a mental and intellectual process in finding a problem and solving it based on accurate data and information so that a proper and careful conclusion can be drawn. Problem-solving methods provide opportunities for learners to play an active role in learning, to seek and to find their own information or data to be processed into concepts, principles, theories or conclusions [18]. Problem-solving skills should be supported by reasoning ability, namely the ability to see a cause and effect relationship [18].

\section{4) Problem solving}

Problem solving is a method of teaching in which students are faced with a problem that must be solved based on data or information that is accurate so that they can draw a conclusion. While problem solving is a mental and intellectual process in finding a problem and solving it based on accurate data and information so that a proper and careful conclusion can be drawn. Problem-solving methods provide_opportunities for learners to play an active role in learning, to seek and to find their own information or data to be processed into concepts, principles, theories or conclusions. Problem-solving skills should be supported by reasoning ability, namely the ability to see a cause and effect relationship [18].

\section{5) Scientific approach to learning}

Scientific approach to learning requires changes in their own settings and forms which are different from conventional learning. Several learning methods considered in line with the principles of scientific approach include: (1) Problem-Based Learning, (2) Project-Based Learning, (3) Inquiry/Social Inquiry, and (4) Group Investigation. These methods enable students to recognize problems, to formulate problems, to find solutions or answers to test assumptions towards a problem/question through investigation (finding facts through sensing), could 
ultimately draw conclusions and present it orally and in writing. The ability of creativity is obtained through: observing, questioning (inquiring), associating (reasoning), experimenting (trying), and networking (network forming) [17].

\section{6) Metaphorming}

Metaphorming is a word derived from the Greek words meta and phora which mean the act of making something meaningful. It begins with moving into a new meaning and associating some ideas into a new idea. It can be said that metaforming is a deep and creative thought. This kind of thinking has a real and useful purpose that is to use the whole power of the efforts of all the organs of our body to become an entity that directs us towards essential thinking. This is a kind of thinking which will bring about the students acceleration in thinking, creativity, finding a new thing, and connecting all things which are apparently not related to become intertwined and eventually lead to the resolution of the problem. This learning will enhance and enrich the learning experience and improve communication between teacher-student, teacher-teacher, teacher-school principals, and principals-student.

\section{Methods}

The present study employed a developmental research using the 4-D (Define, Design, Develop, and Disseminate) model of development [19]. This preliminary research was up to the Develop stage. The subjects were the students of the Culinary Arts of Home Economics Department Faculty of Engineering of State Surabaya University (Unesa). The data were collected using (1) observation to assess the quality of the textbook and other course materials, implementability of the learning, and the learning activities, and (2) questionnaires for the students to discover their responses towards the course materials and implementability of the learning. The collected data were subsequently analyzed using a descriptive-quantitative technique. The research procedure is comprised of three phases (1) Define: determining and defining needs and problems through the front-end, learner, and needs analyses, (2) Design: designing prototype of the course materials, and (3) Develop: revising the prototype on the basis of expert validation. The procedure is summarized in Fig.1.

\begin{tabular}{|l|l|l|}
\hline $\begin{array}{l}\text { Phase 1 } \\
\text { Define } \\
\text { Design }\end{array}$ \\
\begin{tabular}{|l|l|}
\hline $\begin{array}{l}\text { Phase 2 } \\
\text { - front-end analysis } \\
\text { prototype of the } \\
\text { course materials }\end{array}$ \\
needs analysis \\
Develop \\
perototype on the \\
basis of expert \\
validation \\
(developmental \\
testing)
\end{tabular} \\
\hline
\end{tabular}

Fig. 1 The research procedure

\section{Result and Discussion}

The results of this research are described in accordance with their respective research phases: define, design, and develop. The results achieved in this study are described as follows: (1) the development of textbooks on creative thinking and learning strategies; and (2) the lesson planning of the Educational Research Methodology in Culinary Arts course, which included the syllabus and lesson plan units The initial data collection and the try-out were held on October 24-31, 2014 in the Culinary Arts of Home Economics Department. There were twenty four students voluntarily participating in the research.

\section{The 'define' phase}

1) The front-end analysis: The result of the front-end analysis of the preliminary study deals with the course materials and learning tools (syllabus and lesson plan units) used for the purposes of the research. It showed that the presence of the learning materials and tools as the lecturer's gudelines had a complete and good quality. However, there are several matters to be consider for the further stage. They are as follows: (1) not all of the learning objectives were included in the high-level learning objectives (C4-C6: analysis, synthesis, evaluation) or the higher order thinking; (2) the learning methods used were not problem-solving activities; and (3) the use of various instructional media was still lacking. Nonetheless the course materials and learning tools used employed variations in individual, group (cooperative), and pair learning. Based on these results, a decision taken from the beginning of the end of this analysis was that the existing learning tools should be adapted and further developed.

2) The learner analysis: Based on the learner analysis, it showed that students possessed a good level of creative thinking abilities and this can serve as the basis for the development of the course materials and learning tools (syllabus and lesson plan units) which can further enhance the student's ability to think creatively. The results also showed the students'active attitude in the learning process. In the learning process in the classroom, the students had more interactions with their peers and groups after listening to the explanation of the lecturer, so it led to getting a new learning experience. They were quite active in developing necessary behaviors, exchanging ideas, asking questions, and debating. Based on this, the course materials and learning tools to enhance the students' ability to think creatively.

3) The concept analysis: The analysis was conducted using the literature studies to produce a concept of the course materials. The concept of these materials would serve as the structure and the reference for the learning activities in the research and the development of course materials (syllabus and lesson plan units). It covered two topics: Experimental Research Design and Classroom Action Research (CAR). The results of the analysis of this concept was useful for the development of teaching materials in the worksheet. It wouldfunction as a guide for teaching the material presented in class, either in the order and in an integrated way. This defined concept would reflect and in the syllabus content and the lesson plan units as well as learning in the classroom.

4) The task analysis: The results of the task analysis showed that the selected task learning experiences were appropriate for the conditions, objectives, and materials for the students. The learning experience needed to be done by the students was related to the individual and group learning 
through the problem-solving process. Through the process of problem solving, the students were expected to improve their creative thinking skills. Designing the task analysis was referred to the results of the front-end, learner, concept analyses in order to be sustainable. The results of the analyses are listed in the achievement indicators contained in the learning tools.

5) The analysis of learning objectives: This analysis was conducted with reference to the learning outcomes or indicators. In addition, the formulation of learning objectives must be adapted to the higher order thinking). The results of the analysis of these objectives were then listed in the syllabus and lesson plan units as guidelines for the implementation of learning.

\section{a. The 'design' phase}

1) The construct-criterion test: The results of the criteria selection for the test came to an agreement that the assessment guidelines suggested the problem-solving essay form had to be completed by the students during the learning process. The assessment guidelines should be included in the syllabus and lesson plan untis. Nevertheless, the multiple choice items were still possible, but shoud be still oriented to the development of the test takers' higherorder thinking, not merely at the level of thinking of knowledge, understanding and application (C1-C3).

2) The media selection: The initial media selection was done by observation in the classroom activities. The results of the initial observation showed that the Culinary Arts Department provided LCD. A multimedia room was also available, supplemented with the availability of sufficient supporting library books for the implementation of problem solving based learning.

However, a textbook that was concerned with the ability to think creatively was still necessary to develop. Based on this, the media needed to be developed in the learning process is the multimedia.

3) The format analysis: Based on the literature study results, it revealed that the format of the selected learning strategy was a strategy of learning in groups with a modelbased learning and problem-solving process. The format was selected by taking into account the results of the learner analysis which would potentially increase the students' ability to think creatively and show their character behavior as learning individuals. The format revealed the contents of the lesson plan units as learning guidelines for the implementation in the classroom.

4) The initial design: This initial design activities were carried out by preparing the course materials and tools (syllabus and lesson plan units) in accordance with the selection of the referenced media and formats, the selected learning strategies, i.e. strategies metaphorming strategies. This preliminary design process resulted in the draft syllabus and its teaching materials and lesson plan units which were ready for the validation process.

\section{The 'develop' phase}

1) The expert validation of course materials: The assessment of quality of the course materials and learning tools (syllabus and lesson plan units) through the expert validation. The validation assessment used a range of scales. The results of the validation can be described as follows:

a) The expert validation of the textbook: The result of expert validation of the textbook entitled "Study of Creative Thinking by the expert lecturers using a validation sheet with a checklist of a 1-4 scale range (1= poor, $2=$ fair, $3=$ good, and $4=$ excellent $)$. The results of the validation are summarized in Table 1 .

TABLE I. THE RESULT OF EXPERT VALIDATION

\begin{tabular}{clcc}
\hline No. & Things to be assessed & Scores & Category \\
\hline 1 & Design & 3.00 & good \\
2 & Format & 3.33 & good \\
3 & Materials & 3.67 & excellent \\
4 & Language & 3.67 & excellent \\
5 & Presentation & 3,75 & excellent \\
6 & Supporting innovations & 3.67 & excellent \\
& and quality of learning & & excellent \\
\hline
\end{tabular}

b) The students' comprehensibility of the textbook: The results of the students' responses towards the comprehensibility of the textbook using the validation sheet in a form of checklist are as follows. The students stated that the book was arranged to have more in-depth analysis than any other textbook. The majority of the students also stated that the breadth and detail of the textbook coverage was considered to be broad and detailed. In addition, they also stated that the textbook was appropriate for the undergraduate level. They believed that the strength of the book was its positive impact in improving the quality of education.

2) The expert validation of the learning tools: The results of the expert validation of the learning tools process can be shown in the following table.

TABLE II. THE RESULT OF EXPERT VALIDATION OF LEARNING TOOLS

\begin{tabular}{|c|c|c|c|}
\hline \multirow[t]{2}{*}{ No. } & \multirow[t]{2}{*}{$\begin{array}{l}\text { Things to be } \\
\text { assessed }\end{array}$} & \multicolumn{2}{|c|}{$\begin{array}{c}\text { Learning tools for Research \& } \\
\text { Methodology course }\end{array}$} \\
\hline & & Average scores & Category \\
\hline 1 & Identity & 3.67 & excellent \\
\hline 2 & Basic competencies & 3,33 & good \\
\hline 3 & $\begin{array}{l}\text { Achievement } \\
\text { indicators }\end{array}$ & 3.66 & excellent \\
\hline 4 & Learning objectives & 3.33 & good \\
\hline 5 & Materials & 3.33 & good \\
\hline 6 & Learning model & 3.67 & excellent \\
\hline 7 & Learning activities & 3.33 & good \\
\hline 8 & Learning procedure & 3.00 & good \\
\hline 9 & Assessment & 3.50 & excellent \\
\hline 10 & References & 3.36 & good \\
\hline 11 & Language & 3.33 & good \\
\hline 12 & Structure & 3.7 & excellent \\
\hline & $\begin{array}{c}\text { Overall average \& } \\
\text { category }\end{array}$ & 3.421 & good \\
\hline
\end{tabular}

a) The pilot phase: The result of the pilot phase included the data concerning: (1) student learning activities, (2) implementability of the learning, and 3) the student responses towards the lesson.

b) The students' learning activities: The results of observations of the students' learning activities through a checklist using $0-1$ scale range $(0=$ not active; 0.1 $0.4=$ less active; $0.5-1=$ active). The results can be shown in the table below. 
TABLE III THE STUDENTS'LEARNING ACTIVITIES

\begin{tabular}{|c|c|c|}
\hline No & Categories & Students' Percentage \\
\hline 1 & active & 91.7 \\
\hline 2 & less active & 9,1 \\
\hline 3 & not active & 0 \\
\hline
\end{tabular}

c) The implementability of learning: The implementation of learning was observed by using the checklist with a 0 4 scale range $(0=$ failure; $1=$ poor, $2=$ fair, $3=$ good, and $4=$ excellent). The observation results are shown in Table 4 . Table 4 shows that the prepared learning tools were applied in the course, and observed by the observers. The observation showed a good average score of 3.4.

TABLE IV. THE IMPLEMENTABILITY OF LEARNING

\begin{tabular}{llc}
\hline No & Creative thinking aspects reflected in the & Average scores \\
& & \\
\hline 1 & Consson plans & 3.3 \\
2 & Discovery & 3.3 \\
3 & Invention & 3.5 \\
4 & Application & 3.5 \\
\hline & Total & 3.4 \\
\hline
\end{tabular}

d) The students' responses towards the learning process: The implementation of the course as reflected from the students' responses using a questionnaire sheet using 1-4 scale range ( $1=$ poor, $2=$ fair, $3=$ good, and $4=$ excellent $)$. The result can be seen in the following table.

TABLE V. STUDENTS'RESPONSES TOWARDS THE LEARNING

\begin{tabular}{clc}
\hline No & \multicolumn{1}{c}{ Things to be assessed } & Scores \& Category \\
\hline 1 & Materials & 3.56 (excellent) \\
2 & Pedagogical skills & 3.57 (excellent) \\
3 & Skills of developing students' creativity & 3.51 (excellent) \\
\hline
\end{tabular}

e) The observation of the creative thinking activities: The creative thinking activities were assessed by using an observation sheet using 1-4 scale range $(1=$ poor, $2=$ fair, $3=$ good, and $4=$ excellent $)$. The result can be seen in the following table.

TABLE VI. THE CREATIVE THINKING ACTIVITIES

\begin{tabular}{ccccc}
\hline $\begin{array}{c}\text { Average } \\
\text { scores } \\
\&\end{array}$ & \multicolumn{4}{c}{ Creative Thinking Aspects } \\
\cline { 2 - 5 } $\begin{array}{c}\text { category } \\
\text { Average } \\
\text { scores }\end{array}$ & Connection & Discovery & Invention & Application \\
\hline category & good & good & good & good \\
\hline
\end{tabular}

All in all, based on the results of the assessments of the textbooks and course materials and tools, it indicated that they were very well categorized and feasible to implement. They were also able to boost the students' creativity. In addition, they had very good quality and fit for use in the learning. The average score for each aspect achievement obtained very good category with a total score reached 3.41. The level of quality textbooks validated in its every aspect was also supported by the results of the students' assessment after using the textbook. According to the students, the level of in-depth discussion of the book was sufficient. The students also stated that the breadth and detail of textbook coverage arranged to have a broad and detailed level. In addition it also stated that the textbook that has validated a lot of new things as well as the depth in accordance with the program strata.

Along this, the quality levels also showed a similar thing. The learning tools arranged had a good decent category.The results of the analysis of the students' responses also showed that most of them responded positively to the development of the textbooks and learning tools organized to boost their creative thinking, as well as their positive responses towards the implementation of the learning tools. They considered that the lectures were excellent. Furthermore, based on the analysis of creative thinking activities, the students in general were also been doing well in these activities. Almost all the students achieved a score approaching 3:00 or more.

These results are consistent with ones of [11] stating that "The strong belief in a particular teaching perspective, whether product- or process-oriented, may have an impact on the students' creative thinking." They are also supported by the research results [2] exploring the relationship of creative thinking with teaching beliefs, learning experiences, and academic achievement.

These findings are also confirmed by [20] who suggested that creative thinking defined as a mental activity is used to construct a new idea or ideas fluently (fluency) and flexibly (flexibility). [21] added another component of creative thinking that is Sensitivity which is the ability to recognize the existence of a problem or ignore the fact that less fit (misleading fact), and originality or the ability to build ideas are not common.

\section{Conclusion}

Based on the results of the present research conducted in the framework of the development of teaching materials as well as learning devices it can be concluded as follows.

1. The development of the high quality teaching materials such as the textbook entitled "Creative Thinking and Learning Strategies" is capable of supporting the students' learning outcomes through the enhancement of the students' creative thinking skills. Also, the indepth presentation they offer is in accordance with the Bachelor Program of Culinary Arts Education.

2. The development of the materials and tools can add the quality and motivate the students' learning activities.

3. That leads the students to accomplish their learning success.

\section{Acknowledgment}

The author would like to thank all the people for their help directly and indirectly to complete this article: Prof. Dr. Warsono, M.Si. (Rector of Unesa); Prof. Dr. Ekohariadi, M.Pd. (Dean of Faculty of Engineering of Unesa); Prof. Dr. I Wayan Susila, M.T, (Head of Research and Community Service of Unesa); and Dra. Suhartiningsih, M.Pd, (Head of the Home Economics of Unesa).

\section{References}

[1] Rofi'uddin. Model Pendidikan Berpikir Kritis-Kreatif untuk Siswa Sekolah Dasar. [Online]. Available http://www.infodiknas.com/model-pendidikan-berpikir-kritis-kreatifuntuk-siswa-sekolah-dasar-2/, 2009.

[2] Kim, K.H. (2011). The Creativity Crisis: The Decrease in Creative Thinking Scores on the Torrance Test of Creative Thinking. Creativity Research Journal, vol. 23(4), p.p. 285-295, DOI: 10.1080/10400419.2011.627805 
[3] Suastra, I. W. Teaching Science Model For Developing Students' Creative Thinking Ability. Proceedings The 2nd International Seminar on Science Education. Bandung, 2008.

[4] Nur, M. Pengukuran Kemampuan Logika Peserta didik dan Guru YLPI Al Hikmah Surabaya, 2008.

[5] Nur, M. Pengembangan Perangkat Pembelajaran MIPA SMP Berbasis ICT untuk Memfasilitasi Proses Belajar Mengajar Bertaraf Internasional, 2008.

[6] Nur, M. Pengembangan Perangkat Pembelajaran IPA SD untuk Memberi Kemudahan Guru Mengajar dan Peserta didik Belajar IPA dan Keterampilan Berpikir (Batch I Year 1), 2009.

[7] Nur, M. Pengembangan Perangkat Pembelajaran IPA SD untuk Memberi Kemudahan Guru Mengajar dan Peserta didik Belajar IPA dan Keterampilan Berpikir (Batch II Year 2), 2010.

[8] Nur, M. Pengembangan Perangkat Pembelajaran IPA SD untuk Memberi Kemudahan Guru Mengajar dan Peserta didik Belajar IPA dan Keterampilan Berpikir (Batch II IYear 3), 2011.

[9] Nur, M. Pengukuran Kemampuan Logika Guru Baru YLPI Al Hikmah Surabaya, 2011.

[10] McLeod, W. T \& Hanks, P. Eds. The New Collins International Dictionary of the English Language. Graham Brash, 1982.

[11] Wang, A. Y. Contexts of Creativity Thinking: A Comparison on Creative Performance of Student Teachers inTaiwan and the United States. Journal of International and Cross-Cultural Studies, vol. 2 (1), p.p. 1-14

[12] Munandar, U. Pengembangan Kreatifitas Anak Berbakat. Jakarta: Rineka Cipta, 2009

[13] Slameto, Belajar dan Faktor-faktor yang Mempengaruhinya. Jakarta: PT Rineka Cipta, 2003.

[14] Ruggiero, V. R.(1993). Critical Thinking: Supplement to Becoming a Master Student, Rapid City, Michigan: Houghton Mifflin Company.

[15] Sharp, C. Developing young children's creativity: what can we learn from research? National Foundation for Educational Research, Topic Journal, vol. 32, p.p. 5-12, 2004.

[16] Semiawan, C. R. Kreativitas Keberbakatan: Mengapa, Apa, Bagaimana. Jakarta: PT Indeks, 2010.

[17] Sunito. Metaphorming Beberapa Strategi Berpikir Kreatif. Semiawan, C. S. Ed. Jakarta: PT Indeks, 2013.

[18] Hamalik, O. Psikologi Belajar dan Mengajar. Bandung: Sinar Baru Algensindo, 1999.

[19] Thiagarajan, S, Semmel, D.S., \& Semmel, M. I. Instructional Development for Training Tachers of Exceptional Childre: A Sourcebook. Minneapolis, Minnesota: Indiana University, 1974.

[20] Johnson, S. and Siegel, H. $2^{\text {nd }}$ ed. Winch, C. Ed. Teaching Thinking Skill. London: Continuum International Publishing Group, 2010.

[21] Evans, J.R. Creative Thinking. Cincinnati, Ohio: South-Western Publishing Co., 1991 